\title{
Competition and the Location of Overseas Assembly
}

Deborah L. Swenson

UC Davis and NBER

Davis, CA 95616

\begin{abstract}
:
How does international competition affect overseas outsourcing? While it is commonly believed that international competition enables firms to desert high cost countries in favor of low wage locations, the frequency of such responses may be reduced if the movement of outsourcing activities involves sunk costs. To put these factors in perspective, I study the production decisions of participants in the U.S. overseas assembly program (OAP). A number of interesting regularities emerge. First, the strong positive effect of prior participation on current OAP participation probabilities suggests that sunk costs influence outsourcing choices. Such production persistence is especially strong among foreign assemblers who are responsible for completing a large percentage of value-added. Second, increases in own-country costs and declines in competitor-country costs reduce participation probabilities. In addition, while these persistence and cost effects characterize all overseas assembly choices, these effects are much larger for outsourcing in developing countries. Finally, outsourcing responses appear to reflect differences in "market thickness", as cost sensitivity generally rises with competitor presence. Taken together, these observations provide empirical support for modeling approaches that feature search costs and partner availability as determinants of outsourcing decisions.
\end{abstract}

JEL Codes: F1, F2

Keywords: International Outsourcing, Production Decisions, Sunk Costs, Competition

\section{Introduction}


Recent empirical work demonstrates how producer decisions respond to growing competition from low wage countries. Measuring low-wage competition by product imports from low wage locations, Schott (2002) notes that U.S. exports declined for those products experiencing increased competition from low wage countries while Bernard, Jensen and Schott (2006) discover that U.S. plants, and especially those in relatively labor-intensive and low-wage sectors, were more likely to shut down when faced with increased low-wage competition. $^{1}$

Given the large effects of cost competition on U.S. production choices one might expect that outsourcing trade would be especially sensitive to international cost pressures. However, while cost minimization implies that outsourcing firms will locate assembly operations in low cost countries, such responses may be smaller than popularly believed if the creation and maintenance of outsourcing relationships entail sunk costs. Such is the point of Grossman and Helpman's (2005) work which demonstrates how a high wage country may nonetheless attract outsourcing firms if its wage disadvantage is offset by relatively low search or adaptation costs. For this reason, it is important to empirically study the effects of sunk costs and cost competition on outsourcing decisions. ${ }^{2}$

To examine outsourcing production decisions this paper studies the evolution of overseas assembly program (OAP) activities between 1980 and 1994. ${ }^{3}$ This program encompassed a diverse cross-section of U.S. outsourcing imports, as OAP assembly involved

\footnotetext{
${ }^{1}$ These papers define low wage competition by the value share or product share of imports arriving from countries with GDP per capita less than $5 \%$ of the U.S. level. They also note other effects of competition with low wage countries. Schott (2002) observes a greater degree of quality upgrading as indicated by increased export unit values, while Bernard, Jensen and Schott (2006) observe an increased probability that U.S. plants switch product lines.

2 According to Hummels, Ishii \& Yi (2001) vertical specialization accounts for 30 percent of all trade flows. Feenstra (1998), Ng and Yeats (2001) Yeats (2001) and Spencer (2005) for overviews of recent outsourcing trends and theories, or Gorg (2000) and Swenson (2005) for evidence on outsourcing volumes. ${ }^{3}$ By definition, overseas assembly products imported through the OAP program must include some U.S.origin parts, components or materials. The OAP program currently operates under the 9802 rules of the
} 
399 four-digit SIC industries, and 64 different countries. While OAP imports do not include all U.S. outsourcing imports, they represented a non-trivial nine percent of U.S. imports during the sample period.

In contrast with Swenson's (2005) study of overseas assembly export values, this paper studies the extensive margin, using a linear probability model to examine the factors that influenced whether a country participated in overseas assembly, or not. The results show that the probability of exporting OAP products was positively related to prior OAP participation, thus suggesting that sunk costs affected production decisions. In the full sample past year participation was associated with a 21 percent increase in the current probability of OAP activity. The probability of current participation also increased with declines in own-country costs or increases in competitor-country costs.

This paper also contributes to the literature on outsourcing by showing how country or industry characteristics influenced the degree of outsourcing market attachment, and how these differences line up with theoretical models of outsourcing. On the industry dimension project scale, as measured by the foreign assemblers' contribution to value-added, was positively related to the magnitude of production persistence. This supports the idea that sunk search costs were larger for assembly operations that involved more tasks that contributed significantly to project success.

On the country dimension, differences in country development are highlighted since a number of factors could cause cost sensitivity to differ with country development. ${ }^{4}$ For example, if more developed countries produce more highly differentiated goods than those assembled in developing countries, cost changes may play a greater role in decisions

U.S. Harmonized Tariff system. This analysis ends in 1994 since the 4-digit SIC data that are used to create the cost measures are not available for years after 1994.

${ }^{4}$ In related work, Blonigen and Davies (2004) and Blonigen and Wang (2005) show how FDI determinants differ for developed versus developing countries. 
regarding the more homogenous products assembled in developing countries. Alternatively, if high-skill workers are less interchangeable and developed country assembly relies more heavily on high-skilled workers, frictions due to sunk costs of search and investment may help to insulate developed country operations from cost-based production shifts. The empirical analysis confirms the importance of the development dichotomy, as developing country outsourcing assembly responded more vigorously to changes in own or competitor costs.

Finally, I test for "market thickness" externalities in outsourcing assembly, as related to competitor presence. All else equal, the potential to switch from one partner to another depends on the availability of suitable partners in other countries. For example, an appreciation of the Mexican Peso will diminish Mexico's attractiveness as a location for outsourcing assembly. However, since apparel firms have more potential partners in other countries than do firms in other industries, a Peso appreciation may cause more relocation in the apparel industry than in other sectors. To search for this effect empirically, I define "market thickness" by the number of OAP country suppliers in an industry, and test whether competitor presence influenced cost sensitivity. The results show that cost sensitivity was indeed higher in industries populated by a wider range of potential country suppliers.

The rest of the paper is organized as follows. To motivate the regression analysis, section two provides a basic discussion of trade and outsourcing models, to highlight the potential role for sunk costs, and to describe country and industry characteristics that could enhance or reduce the overall sensitivity of outsourcing assembly to country costs. Section three provides a model of outsourcing production decisions to guide estimation. Section four describes the data and estimates the importance of own and competitor costs for outsourcing decisions. A brief conclusion follows in section five.

\section{Modeling Outsourcing Decisions}


Cross-country differences in factor costs affect outsourcing incentives as firms choose the ideal location for each production stage involved in the creation of a final product. $^{5}$ However, while one expects outsourcing decisions to reflect country cost considerations, it is not clear that outsourcing production should respond to all changes in country production costs. As Rauch (1999) notes, informational frictions appear to influence general trade volumes. Similarly, an absence of full information about alternative country partner characteristics and abilities may deter firms from quick outsourcing partner switches when country costs change.

Comparable search and informational issues underpin Grossman and Helpman's (2005) model of outsourcing decisions. While low wages in the South are attractive to producing firms, a firm's decision to undertake costly search for outsourcing partners in the North or South is guided by expected profits. For example, firms may seek partners in the high-wage North if the costs of information gathering and investment coordination in the South outweigh the South's wage advantage. Similarly, if firms experience cost increases in their current assembly location, we expect them to evaluate whether the expected cost savings from a partner search justify the sunk costs of searching for a new outsourcing partner. If search costs are non-negligible, outsourcing choices will be characterized by hysteresis. ${ }^{6}$

Additional sunk costs may further inhibit rapid international sourcing changes. As Grossman and Helpman (2005) describe, fruitful international outsourcing projects may require relationship-specific investments by potential foreign partners. Since weaker legal protections in the South make it difficult to ensure that Southern outsourcing partners will

\footnotetext{
${ }^{5}$ See Deardorff(2001) for a discussion of factor prices and outsourcing, or Yi (2003) for a Ricardian model of outsourcing that accounts for tariffs.

${ }^{6}$ For a discussion of hysteresis in trade, see Baldwin (1988), Baldwin and Krugman (1989), Dixit (1989), or Krugman (1989).
} 
perform all necessary relationship-specific investments, lower Southern wages may be a symptom of the poor legal environment, rather than a special attraction for Southern outsourcing. ${ }^{7}$ In addition, since the North's strong legal environment ameliorates incomplete contracting problems the attractiveness of Northern operations may be further enhanced by "thick market" externalities. In particular, as more firms search for outsourcing partners in the North, more potential partners locate in the North. As a result, the increased density of potential partners in the North increases the probability that firms searching in the North will succeed in locating an appropriate partner.

Overall, a message of these outsourcing models and the work on search costs more generally, is that the effects of cross-country cost differentials may be tempered by sunk costs of search and investment. As a result, we need to empirically examine outsourcing decisions to put these economic factors in perspective.

\section{An Estimation Framework for Assembly Decisions}

To describe outsourcing production choices I modify Roberts and Tybout's (1997) model of export decisions, which examines export choices in the presence of sunk entry costs. Outsourcing operating profits are at the center of such a model. We can model current operating profits for outsourcing assembly of industry i goods in country c as depending on production costs $\left(\mathrm{c}_{\mathrm{i}}\right)$ and competitor country costs $\left(\mathrm{c}_{\mathrm{i}}{ }^{*}\right)$, or $\pi\left(\mathrm{c}_{\mathrm{i}}, \mathrm{c}_{\mathrm{i}}{ }^{*}\right) .{ }^{8}$ Profits naturally rise when own country costs decline. In contrast, reduced competitor costs, which force firms to respond by reducing sales and/or prices, are associated with declines in operating profits.

As in Roberts and Tybout (1997) I assume that firms incur sunk entry costs related to market search or investment each time a new outsourcing relationship is created at the

\footnotetext{
7 Since weak legal systems reduce Southern wages, Grossman and Helpman (2005) show that it is difficult to make simple predictions about the net effects of differential country legal effectiveness on outsourcing decisions.

${ }^{8}$ Time subscripts are initially dropped, though time-specific cost measures are used for estimation.
} 
country-industry level. If outsourcing activities involve sunk costs, firms will engage in outsourcing when outsourcing this period increases firm value by an amount that is greater or equal to the fixed costs associated with the decision to engage in outsourcing production this period. ${ }^{9}$

This basic description of outsourcing decisions generates a number of testable predictions. First, the probability that country c engages in outsourcing assembly of industry i products will be positively related to operating profits. In turn, this predicts that the probability of outsourcing will be negatively related to own-country costs, and positively related to competitor country costs. Second, prior production decisions will influence current production decisions. Since continuation of an outsourcing relationship does not entail fixed entry costs, as does the initiation or renewal of outsourcing assembly, outsourcing probabilities will be higher for country-industry pairs that previously had positive outsourcing activity. Finally, if reentry costs are smaller than the sunk costs of fresh entry, earlier activities will also boost the probability of current activity, though the benefit of more distant activity may be weaker than the effects of activity in the prior period.

To capture these hypotheses, I examine whether country c assembled industry i outsourcing goods in year $\mathrm{t}$, or $\mathrm{Y}_{\mathrm{cit}}=1$. If there is no such assembly, $\mathrm{Y}_{\mathrm{cit}}=0$. The probability of outsourcing this period depends on the profitability of assembling industry i, goods in country c. Variables that influence profits, $\mathrm{X}_{\mathrm{cit}}$, include the cost of producing in country c, as well as the cost of producing goods in country c's competitors.

$$
\mathrm{Y}_{\mathrm{cit}}=\alpha+\beta \mathrm{X}_{\mathrm{cit}}+\theta^{1} \mathrm{Y}_{\mathrm{ci}, \mathrm{t}-1}+\theta^{2}\left(1-\mathrm{Y}_{\mathrm{ci}, \mathrm{t}-1}\right) * \mathrm{Y}_{\mathrm{ci}, \mathrm{t}-2}+\lambda_{\mathrm{c}}+\delta_{\mathrm{i}}+\gamma_{\mathrm{t}}+v_{\mathrm{cit}}
$$

\footnotetext{
9 The increase in firm value is equal to the discounted increase in firm value caused by the decision to outsource industry i goods in country c.
} 
Estimating equation (1) also includes country, industry and time dummies, $\lambda_{\mathrm{c}}, \delta_{\mathrm{i}}$, and $\gamma_{\mathrm{t}}$ to capture country attractiveness for outsourcing, general industry suitability for outsourcing assembly, and common shocks to outsourcing probabilities over time.

The coefficients on previous year production decisions, $\mathrm{Y}_{\mathrm{ci}, \mathrm{t}-1}$ and $\mathrm{Y}_{\mathrm{ci}, \mathrm{t}-2}$, test whether sunk costs influence outsourcing decisions. ${ }^{10}$ In the absence of sunk entry costs, we predict $\theta^{1}=\theta^{2}=0$. In contrast, if outsourcing involves sunk entry costs, these coefficients should be positive. Further, if sunk costs of reentry are smaller than those of initial entry, then recent outsourcing production will elevate current probabilities more than activity in the more distant past, or $\theta^{1}>\theta^{2}>0$.

While specification (1) includes both country and industry effects, we may need to further control for country-industry effects. In particular, cross-industry differences in comparative advantage imply that countries may be attractive for some types of outsourcing assembly, but not all. For example, unobserved country characteristics may attract textile assemblers to Jamaica, while having no similar effect on assemblers in other industries. If this is the case, the estimated coefficient on previous participation may be positive even if there are no sunk costs. To control for the country-industry dimension of unobserved attractiveness, regression specification (2) includes country-industry fixed effects, $\Phi_{\mathrm{ci}}$.

$$
Y_{\text {cit }}=\alpha+\beta X_{\text {cit }}+\theta^{1} Y_{c i, t-1}+\theta^{2}\left(1-Y_{c i, t-1}\right)^{*} Y_{c i, t-2}+\gamma_{t}+\Phi_{c i}+\eta_{c i t} .
$$

The new error term, $\varepsilon_{\mathrm{cit}}=\Phi_{\mathrm{ci}}+\eta_{\mathrm{cit}}$, includes the iid error component $\eta_{\mathrm{cit}}$.

There are many possible econometric approaches for estimating the outsourcing equations as represented in specifications (1) and (2). Following Bernard and Jensen (2004), I estimate outsourcing participation probabilities using a linear probability model. Since

\footnotetext{
${ }^{10}$ I only report coefficients for production in the previous two years, since the coefficients for more distant lags were never statistically significant. Roberts and Tybout (1997) also fail to find any significant effect for lags of more than two years.
} 
random effects estimation yields biased and inconsistent estimates if unobserved outsourcing determinants are correlated with the country-industry effects, $\Phi_{\mathrm{ci}}$, I estimate specification (2) using fixed effects techniques.

\section{Data and Estimation}

\subsection{Data and Summary Statistics}

The key data for this project are based U.S. OAP activity. The dependent variable $\mathrm{Y}_{\text {cit }}$ indicates whether a country exported OAP products to the U.S. in a 4-digit SIC industry in a given year. Since I am interested in including the effects of competitor costs on OAP production decisions, it is important to define which countries competed with each other, and in which industries. To define competition, countries were classified as a potential supplier, or competitor for a particular 4-digit SIC industry if the country exported OAP products in that 4-digit SIC during any of the years in the sample period. As Rodrik (1997) such a definition may exclude countries whose presence at the competitive fringe disciplined and influenced the universe of OAP producers, though they never managed to enter into OAP production. However, the primary benefit of this definition is that it includes all known competitors, while excluding the bulk of countries who were never at risk of providing OAP goods during the sample years. ${ }^{11}$

Table 1 displays the industry composition and competition characteristics of OAP data sample. The breadth of OAP activities is evidenced by the fact that the U.S. purchased OAP imports in 399 of the 450 4-digit manufacturing industries. Across the 399 industries, the average number of competitor countries was 16.6, while the median was 13 competitor

11 Competitors were not defined by presence in general trade flows, since a country that successfully exports an item to the U.S. may or may not be capable of profitably engaging in OAP production. For example, if the costs of exporting U.S. inputs to a distant location overwhelm that location's assembly cost advantages, the country will never participate in OAP assembly, even if it exports final goods from that industry to the U.S. A further disadvantage of using general trade flows to define competitors is that it effectively defines almost all countries as competitors in all industries, since U.S. imports were non-zero for almost all [(4-digit SIC)-country] pairs. 
countries. Nonetheless, while 4-digit products originated from both developed and developing locations - OECD countries shipped OAP products to the U.S. in 387 different industries, while non-OECD suppliers shipped OAP products in 357 industries - the typical OECD producer faced fewer competitors than did the typical non-OECD assembler of OAP products. $^{12}$

If one examines the trade-weighted competitor counts displayed in the final three columns of Table 1 the difference in competition facing developing country OAP producers becomes more dramatic. ${ }^{13}$ In particular, on a trade-weighted basis OECD producers of OAP products faced 31.4 competitor countries while non-OECD producers faced 41.9. Such differences are consistent with Bernard, Jensen and Schott's (2006) observation that U.S. plants altered their product mix to reduce direct competition with low wage countries. In particular, it appears that OECD producers concentrated their efforts in 4-digit industries that were characterized by fewer country competitors.

To highlight differences in competition, activity and input choices across OAP producers, Table 2 displays OAP outsourcing characteristics for individual countries. First, the production percent (Prodn \%) columns list the percent of years in which a country provided products in the industry categories they ever exported OAP products in. For example, if a country only sold one OAP item during the years studied, a production percent of $50 \%$ indicates that it was observed exporting that item to the U.S. for exactly half of the years in the sample. The average for all country-industry pairs was 50.2 percent. $^{14}$ Table 2 also displays trade-weighted competitor numbers. Here cross-country variation is primarily

\footnotetext{
12 Countries were classified as developed if they became OECD members by 1985. Because OECD and non-OECD countries participated in slightly different sets of industries, the competitor averages for the two groups ( 7.7 for OECD and 10.2 for non-OECD assemblers) do not sum to the sample average of 16.6.

${ }^{13}$ The weighted values provide an average number of competitors for each 2-digit SIC industry, where the weight assigned to each 4-digit industry within its 2-digit SIC industry group is the real value of OAP imports of that 4-digit industry over the sample period.
} 
driven by differences in product mix across countries. For example, the number of competitors is especially high for countries such as Honduras or Guatemala, whose main OAP activities were concentrated in textiles and apparel.

The last item displayed in Table 2 is the U.S. Percent, which is the percentage of OAP value-added attributable to U.S.-origin parts, components and materials. While the trade-weighted sample average was almost 53 percent, there was a tremendous divergence between the 9.5 percent observed for the OECD assemblers, as compared with the 62.5 percent for non-OECD participants in the OAP. In addition, both distance and industry composition appears to have influenced the relative usage of U.S. inputs, since the reliance on U.S.-origin inputs was highest for OAP assemblers located in countries near the U.S., and for countries that were heavily engaged in OAP production of textile and apparel products. ${ }^{15}$

\subsection{Empirical Implementation}

A few issues must be addressed before the production equation can be estimated. The first is how to measure own and competitor costs. The benefit of observing OAP imports is that knowledge about the operational features of OAP sourcing enables one to generate measures of own country costs that reflect country costs, input decisions, transportation costs, and tariffs. These country-industry cost measures can then be combined with the country competition definitions to generate competitor cost measures.

As in Swenson (2005), I assume that OAP production is best characterized as a Leontieff production process that requires producers to complete a series of $\mathrm{m}_{\mathrm{i}}$ tasks that

\footnotetext{
14 Positive import observations are generally clustered. For country-industry observations that were positive, there was a $76 \%$ probability that the next period's observation was also positive.

15 The differences due to distance are likely to represent pure transportation costs, as well as issues related to time in transit and its implications for timely production. See Evans and Harrigan (2005). I do not include distance in the estimating equations, since the regressions include country or country-industry dummies which capture the effects of all country characteristics that remained constant over time.
} 
must be performed in sequence. ${ }^{16}$ The final task, $\mathrm{m}_{\mathrm{i}}$, represents final assembly. U.S. producers who produce for OAP complete tasks from 0 to $\alpha_{\mathrm{us}}$. The remaining tasks from $\alpha_{\mathrm{us}}$ to $\mathrm{m}_{\mathrm{i}}$ are completed overseas. Participation in OAP reveals that the U.S. has comparative advantage in parts and components, while foreign countries have comparative advantage in the end of sequence tasks $\alpha_{u s}$ to $m_{i}$ which include assembly. The position of $\alpha_{\text {us }}$ differs for each country-industry as dictated by comparative advantage of the U.S. versus country c in industry i. The position is also influenced by issues of cost minimization in light of tariff and transportation costs.

Total production requires $\mathrm{L}_{\mathrm{i}}$ units of labor. Assuming that each of the $\mathrm{m}_{\mathrm{i}}$ tasks requires $\mathrm{L}_{\mathrm{i}} / \mathrm{m}_{\mathrm{i}}$ units of labor, and U.S. labor costs $\mathrm{w}_{\mathrm{us}}$ while foreign labor costs $\mathrm{w}_{\mathrm{c}}$, production cost is: $:^{17}$

$$
\text { Production Cost } \left.\mathrm{ic}_{\mathrm{ic}}=\left[\alpha_{\mathrm{us}, \mathrm{ic}}{ }^{\mathrm{W}_{\mathrm{us}}}+\left(1-\alpha_{\mathrm{us}, \mathrm{ic}}\right)^{*} \mathrm{~W}_{\mathrm{c}}\right)\right]^{*} \mathrm{~L}_{\mathrm{i}}
$$

Production costs are augmented by transportation costs and tariff surcharges. The advalorem shipment cost $\mathrm{g}_{\mathrm{ic}}$ applies to the import of the final good to the U.S. It also applies to the shipment of U.S. intermediate inputs that are assembled in the overseas facility. Since the OAP program stipulates that U.S. origin parts are exempt from tariff, the U.S. import tariff $\tau_{\mathrm{i}}$ applies only to the foreign portion of value-added. The resulting cost of producing industry $\mathrm{i}$ OAP products in country c is: ${ }^{18}$

$$
\left.\mathrm{C}_{\mathrm{ic}}=\left[\alpha_{\mathrm{us}, \mathrm{ic}} * \mathrm{~W}_{\mathrm{us}}+\left(1-\alpha_{\mathrm{us}, \mathrm{ic}}\right) * \mathrm{~W}_{\mathrm{c}}\right)\right]^{*} \mathrm{~L}_{\mathrm{i}} *\left[1+\mathrm{g}_{\mathrm{ic}}\left(1+\alpha_{\mathrm{us}, \mathrm{ic}}\right)+\left(1-\alpha_{\mathrm{us}, \mathrm{ic}}\right) * \tau_{\mathrm{i}}\right] .
$$

\footnotetext{
${ }^{16}$ The traditional literature on vertical integration uses a Leontieff production structure. See Greenhut and Ohta (1979), or Mendez (1993) for an application to OAP. Yi (2003) creates a more elaborate three stage production structure.

${ }_{17}$ Time subscripts are omitted for simplicity.

${ }^{18}$ Formula 4 was used to create the own and competitor cost regressors. The data appendix provides further details on the creation of the cost measures. Since I assume that the total labor requirement is the same for all locations, $L_{i}$ can be viewed as a scaling factor that has no effect on relative country attractiveness. As a result, I can remove $\mathrm{L}_{\mathrm{i}}$ from (4) when I generate the cost measures, which is convenient since there are no good measures of $\mathrm{L}_{\mathrm{i}}$.
} 
Competitor costs were calculated as competing country costs $\mathrm{C}_{\mathrm{ic}}$ weighted by the real value of OAP imports $\mathrm{V}_{\mathrm{ci}}$ for all countries c producing in industry $\mathrm{i}$. Thus, the competitor cost measure for country $c^{\prime}$ in year $t$ was:

CompetitorCost $\cos _{c^{\prime} i}=\sum_{c \neq c^{\prime}}\left[\frac{V_{c i}}{\sum_{c \neq c^{\prime}} V_{c i}} * C_{i c}\right]$.

A second implementation issue arises since the theory is based on firm-level outsourcing decisions while the data are available at the industry level. Industry data may still provide insight into firm issues if all firms producing industry i goods in county c make similar decisions. This is most likely if their decisions are guided by common shocks and characteristics, such as a large shock to the host country's exchange rate combined with commonality of sunk search costs. The high rates of entry and exit from OAP production at the industry level suggest that firms do make similar decisions or that many country-industry observations were based on a single firm's activities. Alternatively, if the sunk cost efforts of one firm yield information for all potential producers, industry decisions may reflect single firm efforts. For example, if one firm decides to assemble shoes in Indonesia, its actions may provide costless information to other shoe firms. Ultimately, while firm level data is ideal, its absence forces us to cautiously draw inferences from the available data.

The final implementation issue relates to timing. As the J-curve in international trade suggests, trade relationships generally respond to cost changes with a lag. If OAP outsourcing involves search and set-up time, as well as a time-lag associated with the termination of old contracts, current production decisions are likely to reflect cost information from earlier periods. As a result, I use lagged cost measures to represent the cost 
information guiding current production decisions. For this reason, the own and competitor cost terms are both lagged two periods in my preferred specification. ${ }^{19}$

\subsection{Results}

The results displayed in Table 3 support the idea that sunk costs shaped outsourcing decisions. For example, the OLS estimates in column (1) show that OAP outsourcing probabilities were 45 percent higher for country-industry combinations that involved OAP production in the preceding period. However, this correlation will also arise if there are unobserved factors in country c's production of industry i goods that gives the country a productivity advantage over other country locations. Such productivity differences could be driven by differences in the costs of doing business in alternative locations, or they could reflect differences in country abilities to produce in particular industry. Indeed, since further regressions indicate the presence of persistent country-industry advantages, the remaining analysis includes a full set of country-industry fixed effects. ${ }^{20}$

In the full sample, fixed effects estimation suggests that countries that produced for OAP had a greater probability of producing OAP products in the same industry in the following year, though the benefit is now 21 percent in magnitude. Since the effect of OAP production two periods earlier loses significance in the fixed effects setting it appears that more distant OAP experience was not an important factor in current OAP participation decisions. This may be because sunk costs were based on firm-level sunk costs of information-gathering and firm-level relationship-specific investments, rather than general

\footnotetext{
${ }^{19}$ The regression fit is best when costs are measured with two lags, rather than one. However, the qualitative results are unaffected by the choice of lag length.

${ }^{20}$ When the regressor (Produce $\left.{ }_{t-1}\right) *($ Own-Cost) is added to the basic OLS regression, it has a negative and significant coefficient of -.153(.012). This indicates that part of the observed production persistence arises from unobserved sources of country-industry advantage.
} 
sunk costs at the country level. Since OAP activity lagged two years has no explanatory power, the two-year lag is dropped as a regressor from this point onward. ${ }^{21}$

The results also show that a country's probability of producing OAP products fell when its costs increased, and increased when competitor costs rose. In the full sample, a one standard deviation increase in own costs would cause current production probability to decline by $7.5 \%$ This result is consistent with other work on competition in international trade, such as Goldberg and Knetter's (1995) demonstration that export volumes decline when competitor costs decrease, or Bernard, Jensen and Schott's (2006) discovery that competition with low-wage exporters diminishes and alters the exports of U.S. plants.

Finally, changes in capital-intensity affected OAP countries differentially by country type. In particular, while OAP producers in developed countries experienced an increased probability of producing OAP products when capital-intensity rose, the production probabilities for developing country OAP producers were negatively correlated with increases in capital- intensity. ${ }^{22}$

\section{Development and Sourcing}

There are many reasons why developed and developing country outsourcing may respond differently to changes in economic factors. ${ }^{23}$ First, if assembly in low wage locations utilizes more unskilled labor, and low-skilled workers are more easily substituted across countries than are high-skilled workers, then cost shifts are likely to foster more

\footnotetext{
${ }^{21}$ Creation of lagged variables reduces the size of the data set used in estimation. Thus, use of a single lag brings the additional benefit of expanding the data panel to include OAP export decisions in 1981. If column (3) of Table 3 is re-estimated after adding 2-period lags of participation, the coefficients on $\mathrm{Y}_{\mathrm{ci}, \mathrm{t}-2}$ are .004(.008) for developed and .003(.008) for developing countries, both of which are statistically insignificant.

${ }^{22}$ These results may also reflect reverse causality if U.S. industries become more capital-intense over time as they shifted less labor-intense activities overseas.

${ }_{23}$ Swenson's (2005) study of outsourcing trade volumes uncovers differential effects for developing and developed countries.
} 
relocation in developing country outsourcing assembly. ${ }^{24}$ Second, greater skill abundance in developed countries may enable developed country assemblers to produce goods that are more highly differentiated from their competitors. Thus, if products assembled in developing countries are generally more substitutable than those assembled in developed countries, cost changes are likely create greater relocation pressures for developing country producers. Finally, differences in infrastructure, and the availability of information will affect the sunk costs of information gathering. If these factors differ systematically with country development, then the effects of sunk costs, and hence production persistence, will be different for the two sets of countries.

When OAP production responses are allowed to vary by country development two differences stand out. First, as the third column of Table 3 shows, the effects of own cost increases are more detrimental to developing country assembly operations. Second, past production exerts a greater positive effect on the probability of conducting current OAP production in developing countries, which suggests that sunk costs are larger for OAP operations in developing countries. In a search context, this may imply that it is more difficult and costly to identify suitable partners in developing countries than it is to locate partners in developed locations.

\section{Industry Characteristics and Production Persistence}

Table 4 examines whether OAP production persistence was related to underlying industry characteristics in a fashion that supports sunk cost arguments. To begin, it is natural to ask whether sunk costs were larger in capital-intense industries, since capital-intensity indicates that production is likely to involve greater investment in capital. In addition, if capital-intense industries involve more complex production processes, it may be more costly

\footnotetext{
${ }^{24}$ Head and Ries's (2002) examination of Japanese multinationals suggests that Japanese firms hire more unskilled workers in low-income locations, and higher skilled workers in high-income locations.
} 
to search for partners who possess the skills required by such projects. To test whether production persistence varied with industry capital-intensity, I added an interaction term between previous participation and capital-intensity. However, the coefficients displayed in column (1) of Table 4 indicate that capital intensity had no effect on the importance of continuity in current production decisions.

An alternative possibility is that production persistence is driven by sunk costs are associated with partner importance, where partner importance is gauged by the fraction of project value that originates in the U.S. For example, if the U.S. percentage of project valueadded is high it may be easier to locate another assembler who is capable of performing the assembly tasks, since the foreign assembler's contribution to value-added is small. In contrast, if the foreign assembler makes a substantial contribution to value-added it may be more difficult to locate alternative partners who are capable of performing the full range of tasks performed by the current partner. To test this idea, the regression reported in column (2) of Table 4 includes an interaction between the U.S. percentage of project value-added, and the dummy for previous year participation. The new results indicate that the value of previous participation was lower when the U.S. percentage was high: previous OAP activity had a larger effect on current participation probabilities when foreign producers were responsible for a relatively large portion of project value. Presumably, foreign assemblers making small contributions were more easily replaced, since the sunk costs of finding another bit-partner and organizing the new partnership were lower. ${ }^{25}$

The results in Table 2 suggested that previous period OAP participation elevates current participation probabilities by 13 percent for developed countries, and 29.2 percent for developing countries. If one accounts for the different input choices of developing and

\footnotetext{
${ }^{25}$ Due to its significance, the interaction term based on the fraction of U.S. value-added is included in all regressions from this point onward.
} 
developed country producers, by using the trade-weighted input averages taken from Table 2, the difference in production persistence for developing and developed countries narrows a small amount. Nonetheless, the OECD producer's benefit of previous participation - a 16.2 percent increase in current production probability - is still smaller than the non-OECD producer's benefit, which is a 24.1 percent increase in production probabilities due to previous period production.

To evaluate whether the regression predictions from the linear probability model were reasonable, I calculated the probabilities that were implied by the results. For example, the predicted probabilities based on the specification displayed in column (2) of Table 4 are all positive, taking values that range from .007 to 1.16 . However, most observations have predicted probabilities that are closer to our expectation. The median prediction of .467 is close to the sample average of .502. Further, most predicted values were in a much tighter range: the predicted probability for the bottom 1st percentile in the sample was .236 and .963 for the top 99th percentile in the sample. If the sample was broken down based on country development, the predicted probability for OECD producers was .482 , which was only slightly lower than the true probability of .511. Among non-OECD producers, the prediction of .520 was close to the true probability of .494 .

\section{Search and Market Thickness}

Market thickness effects are central to Grossman and Helpman's (2005) and McClaren's (2000) descriptions of outsourcing, since market thickness influences the relative attractiveness of searching in one market versus another, of searching for a partner versus conducting more expensive FDI production of inputs, or the attractiveness of engaging in outsourcing through arm's-length arrangements. One way to characterize market thickness for OAP markets is to measure "thickness" by the count of countries producing products in a particular 4-digit industry, and assuming that a higher number of country assemblers 
represents "market thickness". Grossman and Helpman (2005) show that a greater density of partners in one country increases the likelihood that firms will search there. Similarly, a higher presence of potential partners outside the current assembly location should increase the probability that firms will be willing to make a search if cost conditions change. In each case, all else equal, firms that have more potential partners should be more inclined to search, since the increased probability of locating a suitable partner increases the expected profits associated with search.

I incorporate "market thickness" in the estimating equation by adding interactions between the cost terms and competitor counts. Further, given the dichotomous results for assembly in developing and developed countries, I use tests that are based on two different competitor counts at the industry level. The first defines competition by all OAP producers, while the next is based on developing country OAP producers alone. ${ }^{26}$

When competition is defined by all OAP producers, the results in column (1) of Table 5 show that greater market thickness increases the sensitivity of developing country participation probabilities to own-country costs. However, a better regression fit is achieved when competitors are defined using counts of developing country producers. Under this definition, the results displayed in column (2) of Table 5 indicate that market thickness in the number of developing country competitors had an especially strong effect on cost sensitivity for developing country producers. The effects of competitor costs also depend on market thickness: when there are more producers in the market, a country's production probability rises by a larger amount when the average cost of its competitors rises. ${ }^{27}$

\footnotetext{
26 Developing country counts capture the flavor of low-wage competition examined in Bernard, Jensen, and Schott (2006), and Schott (2002). However, it is not possible to use the same set of countries to define low-wage competition, since these countries were generally absent from OAP assembly.

27 The effect of competitor cost changes, when measured by the linear representation $\{\varphi 1+\varphi 2 *[\#$ of Competitors] $\}$, has the undesirable implication that competitor cost rises reduce production probabilities for producers in industries that had few competitors, while it increased the production probabilities the most
} 


\subsection{Conclusions}

This paper analyzes how competition and production persistence influenced OAP outsourcing decisions. While OAP participation probabilities fall when a country's own costs rise and rise when competitor countries' costs increase, the data suggest that outsourcing decisions are not without friction. In the full sample, the U.S. was 21 percent more likely to engage in OAP assembly in a country-industry, where it had OAP assembly in the previous year. The fact that OAP outsourcing probabilities are positively related to previous OAP participation suggests that sunk costs have a large effect on OAP assembly location choices, thus contributing to the mounting evidence of sunk cost effects in export relationships more generally. $^{28}$

The results also show that the degree of market attachment is related to country and industry characteristics which are featured in models of outsourcing. Most notably, previous participation and cost changes exert a larger effect on outsourcing assembly operations in developing countries. The differential in cost sensitivities implies that developing country operations are more easily substituted across country locations, while the differential sensitivity to previous production decisions suggests that outsourcing projects in developing countries involve larger sunk costs of learning about partners, and in making relationshipspecific investments. The benefits of previous participation are especially large when the foreign assembler makes a significant contribution to the overall project's value-added.

for producers in industries with a large number of competitors. Based on the mean number of competitors facing producers in this sample, the predicted effect is positive, as expected.

If Table 5's regressions are re-estimated, with a single coefficient on the direct effect of competitor cost, the coefficient is positive and significant as before. While the remaining coefficients are unaffected, the direct effect is .080 for developed countries, and .044 for developing countries in both regressions 1) and 2) of Table 5. However, removing the linear representation based on competitor presence reduces the regression $\mathrm{R}^{2}$ s considerably, to .066 and .110 , respectively. 
In addition, outsourcing responses also appear to reflect differences in "market thickness". When industries are characterized by the number of alternative OAP outsourcing partners, the detrimental effects of own-cost increases were found to be more pronounced in “thick markets", with sensitivities that were again largest for developing country producers. Taken together, these observations provide empirical support for modeling approaches that feature search costs or partner availability as determinants of outsourcing decisions.

In relating these results to outsourcing more generally, it is important to remember that the OAP program is designed to facilitate foreign assembly of final products that incorporate U.S. materials or components. If OAP assembly is generally less complex than other forms of outsourcing, then the outsourcing frictions described by Grossman and Helpman (2005) are likely to reduce country relocation even further in other outsourcing contexts. Nonetheless, while sunk costs of search or investment may slow the country relocation of outsourcing operations, it is important to remember that outsourcing assembly is still likely to move towards the lowest cost locations in the long run. In this sense, search costs may temper the volatility and disruption associated with changes in international production patterns, even if industries inevitably migrate in particular directions.

\footnotetext{
${ }^{28}$ Aside from Das, Roberts and Tybout (2006), who use a structural model and rich firm level information to identify sunk costs in export decisions, Roberts and Tybout (1997), Campa (2004) and Bernard and Jensen (2004) provide indirect evidence that supports sunk cost theories of exporting.
} 
TABLE 1: OAP COMPETITION BY INDUSTRY.

\begin{tabular}{|c|c|c|c|c|c|c|c|c|c|}
\hline & \multicolumn{6}{|c|}{ COMPETITOR NUMBERS } & \multirow{2}{*}{\multicolumn{3}{|c|}{$\begin{array}{c}\text { TRADE WEIGHTED } \\
\text { COMPETITOR } \\
\text { NUMBERS } \\
\text { OAP Provider }\end{array}$}} \\
\hline & \multicolumn{2}{|c|}{ All Countries } & \multicolumn{2}{|c|}{$\begin{array}{l}\text { OECD } \\
\text { Participants }\end{array}$} & \multicolumn{2}{|c|}{$\begin{array}{l}\text { Non-OECD } \\
\text { Participants }\end{array}$} & & & \\
\hline Industry & $\begin{array}{l}\text { \# of } \\
\text { SICs }\end{array}$ & $\begin{array}{l}\text { Avg. } \\
\text { Count }\end{array}$ & $\begin{array}{l}\text { \# of } \\
\text { SICs }\end{array}$ & $\begin{array}{l}\text { Avg. } \\
\text { Count } \\
\text { OECD }\end{array}$ & $\begin{array}{l}\# \text { of } \\
\text { SICs }\end{array}$ & $\begin{array}{l}\text { Avg. } \\
\text { Count } \\
\text { Non- } \\
\text { OECD }\end{array}$ & All & OECD & $\begin{array}{l}\text { Non- } \\
\text { OECD }\end{array}$ \\
\hline $\begin{array}{l}\text { All } \\
\text { Industries }\end{array}$ & 399 & 16.6 & 387 & 7.7 & 357 & 10.2 & 35.6 & 31.4 & 41.9 \\
\hline SIC 20 & 27 & 2.9 & 23 & 1.8 & 13 & 2.8 & 9.4 & 6.1 & 9.9 \\
\hline SIC 22 & 28 & 11.6 & 28 & 4.3 & 27 & 7.6 & 53.3 & 12.3 & 55.8 \\
\hline SIC 23 & 33 & 35.6 & 33 & 8.9 & 33 & 26.7 & 52.6 & 52.2 & 52.7 \\
\hline SIC 24 & 17 & 8.5 & 17 & 4.6 & 14 & 4.8 & 21.0 & 9.5 & 23.7 \\
\hline SIC 25 & 13 & 25 & 13 & 11 & 13 & 14 & 25.1 & 25.1 & 25.2 \\
\hline SIC 26 & 15 & 12.5 & 14 & 7.1 & 15 & 5.9 & 24.1 & 18.4 & 24.4 \\
\hline SIC 27 & 13 & 6.5 & 13 & 4 & 8 & 4 & 18.4 & 15.1 & 18.7 \\
\hline SIC 28 & 23 & 4.9 & 19 & 3.7 & 19 & 2.2 & 6.8 & 7.8 & 5.6 \\
\hline SIC 29 & 5 & 5 & 4 & 3.5 & 5 & 2.2 & 7.9 & 7.8 & 7.9 \\
\hline SIC 30 & 6 & 21 & 6 & 9.5 & 5 & 14 & 26.9 & 34.1 & 26.3 \\
\hline SIC 31 & 11 & 17.8 & 10 & 4.8 & 11 & 13.5 & 27.3 & 30.8 & 27.2 \\
\hline SIC 32 & 20 & 5.1 & 20 & 2.8 & 15 & 3.1 & 10.3 & 11.3 & 9.5 \\
\hline SIC 33 & 25 & 16.3 & 25 & 9.6 & 22 & 7.5 & 25.6 & 15.1 & 38.1 \\
\hline SIC 34 & 32 & 12.6 & 32 & 7.4 & 30 & 5.5 & 21.6 & 18.5 & 23.8 \\
\hline SIC 35 & 44 & 19.2 & 44 & 11.4 & 42 & 8.1 & 37.0 & 34.2 & 41.0 \\
\hline SIC 36 & 39 & 27.8 & 39 & 12.2 & 39 & 15.6 & 24.4 & 41.1 & 43.7 \\
\hline SIC 37 & 16 & 19.6 & 16 & 10.6 & 14 & 10.2 & 31.4 & 31.1 & 34.5 \\
\hline SIC 38 & 13 & 29.5 & 13 & 14.1 & 13 & 15.5 & 33.8 & 32.4 & 34.4 \\
\hline SIC 39 & 18 & 16.9 & 18 & 6.5 & 18 & 10.4 & 28.1 & 22.4 & 28.7 \\
\hline
\end{tabular}

"\# of SICs" is the count of 4-digit industries in each 2-digit industry category. "Count" is the count of countries who exported products within a 4-digit SIC industry category during the sample period. "Count OECD" and "Count non-OECD" is the count of only OECD or non-OECD country providers. Average Counts (Avg. Count) represent the average over 4-digit SIC industries within a 2-digit SIC industry. "Trade Weighted Competitor Numbers" are trade weighted number of competitors, of all origins, faced in the sample as a whole (All column) or by OECD or non-OECD providers. 
TABLE 2: CHARACTERISTICS OF COUNTRY OAP PROVISION.

\begin{tabular}{|c|c|c|c|c|c|c|c|}
\hline Country & Prodn \% & Comp \# & US \% & Country & Prodn \% & Comp \# & US \% \\
\hline Argentina & 12.0 & 24.8 & 59.5 & Japan & 44.7 & 32.0 & 3.7 \\
\hline Australia & 25.9 & 32.0 & 6.4 & Malaysia & 34.4 & 50.5 & 50.8 \\
\hline Austria & 16.9 & 31.8 & 28.0 & Mauritania & 23.7 & 40.5 & 71.6 \\
\hline Barbados & 70.5 & 50.3 & 66.4 & Mexico & 71.1 & 38.4 & 53.7 \\
\hline Belize & 83.4 & 58.9 & 71.2 & Morocco & 14.8 & 38.6 & 39.4 \\
\hline Belgium & 26.3 & 31.0 & 4.0 & Mozambique & 40.5 & 34.6 & 49.9 \\
\hline Bangladesh & 12.3 & 41.9 & 8.5 & Mauritius & 19.3 & 45.0 & 33.4 \\
\hline Bolivia & 15.7 & 36.2 & 90.1 & Nepal & 20.2 & 60.4 & 4.8 \\
\hline Canada & 71.6 & 31.0 & 27.3 & Netherlands & 27.7 & 29.8 & 22.8 \\
\hline Chile & 17.8 & 40.6 & 30.3 & New Zealand & 13.5 & 29.1 & 15.6 \\
\hline China & 27.5 & 33.9 & 13.3 & \begin{tabular}{|l|} 
Norway \\
\end{tabular} & 15.6 & 20.7 & 31.3 \\
\hline Colombia & 40.3 & 55.0 & 56.5 & Pakistan & 9.7 & 38.4 & 12.2 \\
\hline Costa Rica & 44.3 & 52.2 & 68.9 & Panama & 32.1 & 55.4 & 59.4 \\
\hline Denmark & 20.3 & 33.8 & 8.2 & Peru & 18.8 & 44.7 & 61.1 \\
\hline $\begin{array}{l}\text { Domincan } \\
\text { Republic } \\
\end{array}$ & 47.2 & 51.7 & 68.4 & Philippines & 38.8 & 47.5 & 50.1 \\
\hline Egypt & 20.8 & 48.5 & 7.4 & Poland & 23.2 & 41.0 & 20.2 \\
\hline El Salvador & 44.7 & 52.3 & 60.0 & Portugal & 19.4 & 39.4 & 34.9 \\
\hline Finland & 16.4 & 25.5 & 16.0 & Romania & 12.5 & 46.5 & 9.5 \\
\hline France & 36.7 & 24.9 & 12.4 & Sierra Leone & 45.6 & 55.2 & 68.6 \\
\hline Germany & 40.1 & 32.1 & 2.2 & Singapore & 38.8 & 48.2 & 27.5 \\
\hline Greece & 27.9 & 37.0 & 55.0 & South Africa & 14.1 & 38.4 & 35.4 \\
\hline Guatamala & 52.3 & 59.8 & 52.5 & South Korea & 37.0 & 37.5 & 22.8 \\
\hline Guyana & 58.0 & 59.7 & 67.9 & Spain & 16.4 & 37.4 & 18.6 \\
\hline Haiti & 66.8 & 46.5 & 69.8 & Sri Lanka & 29.6 & 45.5 & 21.8 \\
\hline Honduras & 51.6 & 56.1 & 71.6 & $\begin{array}{l}\text { St. } \\
\text { Kitts/Nevis }\end{array}$ & 53.9 & 49.2 & 64.8 \\
\hline Hong Kong & 23.2 & 49.9 & 36.6 & \begin{tabular}{|l|} 
Sweden \\
\end{tabular} & 34.2 & 31.6 & 3.0 \\
\hline Hungary & 20.3 & 34.9 & 18.7 & Switzerland & 29.0 & 29.8 & 20.8 \\
\hline Indonesia & 22.0 & 40.5 & 37.4 & \begin{tabular}{|l} 
Thailand \\
\end{tabular} & 24.4 & 46.9 & 54.4 \\
\hline Ireland & 30.0 & 42.0 & 26.2 & Trinidad & 54.7 & 49.5 & 43.8 \\
\hline Israel & 17.3 & 16.6 & 42.9 & Turkey & 18.3 & 60.0 & 3.2 \\
\hline Italy & 36.4 & 26.6 & 22.1 & \begin{tabular}{|l|} 
United \\
Kingdom
\end{tabular} & 40.6 & 28.9 & 11.0 \\
\hline Jamaica & 46.9 & 48.4 & 76.1 & Venezuela & 12.6 & 33.2 & 64.2 \\
\hline $\begin{array}{l}\text { All } \\
\text { Countries }\end{array}$ & 50.2 & 35.6 & 52.9 & \begin{tabular}{|l|} 
OECD \\
Countries \\
\end{tabular} & 51.2 & 31.4 & 9.5 \\
\hline & & & & $\begin{array}{l}\text { non-OECD } \\
\text { Countries }\end{array}$ & 49.4 & 41.9 & 62.5 \\
\hline
\end{tabular}

Notes: Prodn \% is the percentage of country-industry-year observations that were positive for country-industry pairs that were ever observed in the OAP dataset. Comp \# and US \% are weighted averages, which use the real value of country-industry OAP imports as weights. Comp \# describes the average number of country competitors, while US \% reports the average US contribution to product value relative to the total product value. 
Table 3: The Effects of Cost Competition on Production Decisions.

\begin{tabular}{|c|c|c|c|c|}
\hline & (1) & (2) & \multicolumn{2}{|c|}{ (3) } \\
\hline & OLS & $\mathrm{FE}$ & \multicolumn{2}{|c|}{ FE } \\
\hline & & & $\begin{array}{c}\text { Developed } \\
\text { Country }\end{array}$ & $\begin{array}{c}\text { Developing } \\
\text { Country }\end{array}$ \\
\hline Own Cost $t_{t-2}$ & $\begin{array}{l}-.107^{\mathrm{a}} \\
(.009)\end{array}$ & $\begin{array}{l}-.242^{\mathrm{a}} \\
(.014)\end{array}$ & $\begin{array}{l}-.088^{\mathrm{a}} \\
(.022)\end{array}$ & $\begin{array}{l}-.195^{\mathrm{a}} \\
(.017)\end{array}$ \\
\hline Competitor Cost $t_{t-2}$ & $\begin{array}{l}.034^{\mathrm{a}} \\
(.004)\end{array}$ & $\begin{array}{l}.065^{\mathrm{a}} \\
(.017)\end{array}$ & $\begin{array}{l}.081^{\mathrm{a}} \\
(.024)\end{array}$ & $\begin{array}{l}.037^{b} \\
(.019)\end{array}$ \\
\hline Produce $_{t-1}$ & $\begin{array}{l}.447^{\mathrm{a}} \\
(.004) \\
\end{array}$ & $\begin{array}{l}.209^{\mathrm{a}} \\
(.005)\end{array}$ & $\begin{array}{l}.130^{\mathrm{a}} \\
(.007) \\
\end{array}$ & $\begin{array}{l}.292^{\mathrm{a}} \\
(.006)\end{array}$ \\
\hline Produce $_{t-2}$ & $\begin{array}{l}.077^{\mathrm{a}} \\
(.006)\end{array}$ & $\begin{array}{l}.009 \\
(.006)\end{array}$ & & \\
\hline $\begin{array}{l}\text { Capital intensity } \\
\text { *Developed } \\
\text { Country } \\
\end{array}$ & $\begin{array}{l}.012^{b} \\
(.006)\end{array}$ & $\begin{array}{l}.096^{\mathrm{a}} \\
(.015)\end{array}$ & $\begin{array}{c}-.012 \\
(.014)\end{array}$ & \\
\hline $\begin{array}{l}\text { Capital Intensity } \\
\text { *Developing } \\
\text { Country } \\
\end{array}$ & $\begin{array}{l}-.069^{\mathrm{a}} \\
(.006)\end{array}$ & $\begin{array}{l}-.093^{\mathrm{a}} \\
(.016)\end{array}$ & & $\begin{array}{l}-.011 \\
(.015)\end{array}$ \\
\hline Controls & $\begin{array}{c}\text { Year, } \\
\text { Country, } \\
\text { SIC2 }\end{array}$ & $\begin{array}{c}\text { Year, } \\
\text { Country- } \\
\text { SIC4 } \\
\end{array}$ & \multicolumn{2}{|c|}{ Year, Country-SIC4 } \\
\hline Adjusted $\mathrm{R}^{2}$ & .440 & .122 & \multicolumn{2}{|c|}{.263} \\
\hline Observations & 44,167 & 44,167 & \multicolumn{2}{|c|}{47,936} \\
\hline
\end{tabular}

Notes: Standard Errors in ( ). The subscripts ${ }^{a}$ and ${ }^{b}$ represent statistical significance at the 1 and $5 \%$ respectively. 


\begin{tabular}{|c|c|c|c|c|}
\hline & \multicolumn{2}{|c|}{ (1) } & \multicolumn{2}{|c|}{ (2) } \\
\hline & $\begin{array}{l}\text { Developed } \\
\text { Country }\end{array}$ & $\begin{array}{c}\text { Developing } \\
\text { Country }\end{array}$ & $\begin{array}{l}\text { Developed } \\
\text { Country }\end{array}$ & $\begin{array}{c}\text { Developing } \\
\text { Country }\end{array}$ \\
\hline Own Cost ${ }_{t-2}$ & $\begin{array}{l}-.088^{\mathrm{a}} \\
(.022)\end{array}$ & $\begin{array}{l}-.195^{\mathrm{a}} \\
(.017)\end{array}$ & $\begin{array}{l}-.085^{\mathrm{a}} \\
(.022)\end{array}$ & $\begin{array}{l}-.191^{\mathrm{a}} \\
(.017)\end{array}$ \\
\hline Competitor Cost $\mathrm{t}_{\mathrm{t}-2}$ & $\begin{array}{l}.081^{\mathrm{a}} \\
(.024)\end{array}$ & $\begin{array}{l}.037^{b} \\
(.019)\end{array}$ & $\begin{array}{l}.080^{\mathrm{a}} \\
(.024)\end{array}$ & $\begin{array}{l}.043^{\mathrm{a}} \\
(.019)\end{array}$ \\
\hline Capital Intensity & $\begin{array}{l}-.013 \\
(.014)\end{array}$ & $\begin{array}{l}-.012 \\
(.015)\end{array}$ & $\begin{array}{l}-.013 \\
(.014)\end{array}$ & $\begin{array}{l}-.016 \\
(.015)\end{array}$ \\
\hline Produce $_{t-1}$ & $\begin{array}{l}.129^{\mathrm{a}} \\
(.007) \\
\end{array}$ & $\begin{array}{l}.301^{\mathrm{a}} \\
(.012) \\
\end{array}$ & $\begin{array}{l}.175^{\mathrm{a}} \\
(.011)\end{array}$ & $\begin{array}{l}.400^{\mathrm{a}} \\
(.011)\end{array}$ \\
\hline $\begin{array}{c}\text { Produce }_{\mathrm{t}-1} \\
\text { *Capital- } \\
\text { Intensity }\end{array}$ & $\begin{array}{l}.001 \\
(.002)\end{array}$ & $\begin{array}{l}-.023 \\
(.025)\end{array}$ & & \\
\hline $\begin{array}{l}\text { Produce }_{\mathrm{t}-1} \\
\quad * \text { US \% }\end{array}$ & & & $\begin{array}{l}-.141^{\mathrm{a}} \\
(.023)\end{array}$ & $\begin{array}{l}-.253^{\mathrm{a}} \\
(.022)\end{array}$ \\
\hline Controls & \multicolumn{2}{|c|}{ Year, Country-SIC4 } & \multicolumn{2}{|c|}{ Year, Country-SIC4 } \\
\hline$\overline{\mathrm{R}^{2}}$ & \multicolumn{2}{|c|}{.262} & \multicolumn{2}{|c|}{.235} \\
\hline Observations & \multicolumn{2}{|c|}{47,936} & \multicolumn{2}{|c|}{47,936} \\
\hline
\end{tabular}

Notes: Standard Errors in ( ). The regressions are estimated by fixed effects [FE]. The subscripts ${ }^{\mathrm{a}}$ and ${ }^{\mathrm{b}}$ represent statistical significance at the 1 and $5 \%$ respectively. 
Table 5: The Effect of Competition on Production Cost Sensitivity.

\begin{tabular}{|c|c|c|c|c|}
\hline & \multicolumn{2}{|c|}{ (1) } & \multicolumn{2}{|c|}{ (2) } \\
\hline & Developed & Developing & Developed & Developing \\
\hline Own Cost $t_{t-2}$ & $\begin{array}{l}-.133^{\mathrm{a}} \\
(.040)\end{array}$ & $\begin{array}{l}-.131^{\mathrm{a}} \\
(.039)\end{array}$ & $\begin{array}{l}-.138^{\mathrm{a}} \\
(.034)\end{array}$ & $\begin{array}{l}-.146^{\mathrm{a}} \\
(.033)\end{array}$ \\
\hline $\begin{array}{l}\text { Competitor } \\
\text { Cost }_{t-2}\end{array}$ & $\begin{array}{l}-.120^{b} \\
(.063)\end{array}$ & $\begin{array}{l}-.301^{\mathrm{a}} \\
(.053)\end{array}$ & $\begin{array}{l}.015 \\
(.053)\end{array}$ & $\begin{array}{l}-.137^{\mathrm{a}} \\
(.050)\end{array}$ \\
\hline Competitor Count & \multicolumn{2}{|c|}{ All Producers } & \multicolumn{2}{|c|}{$\begin{array}{l}\text { Developing Country } \\
\text { Producers }\end{array}$} \\
\hline $\begin{array}{c}\text { Own Cost }{ }_{\mathrm{t}-2} \\
\text { * Competitor } \\
\text { Count }\end{array}$ & $\begin{array}{c}.0003 \\
(.0011)\end{array}$ & $\begin{array}{l}-.003^{\mathrm{a}} \\
(.001)\end{array}$ & $\begin{array}{c}.0019 \\
(.0014)\end{array}$ & $\begin{array}{l}-.003^{b} \\
(.001)\end{array}$ \\
\hline $\begin{array}{c}\text { Competitor Cost }_{\mathrm{t}-2} \\
* \text { Competitor } \\
\text { Count }\end{array}$ & $\begin{array}{l}.014^{\mathrm{a}} \\
(.004)\end{array}$ & $\begin{array}{l}.022^{\mathrm{a}} \\
(.003)\end{array}$ & $\begin{array}{c}.007 \\
(.005)\end{array}$ & $\begin{array}{l}.016^{\mathrm{a}} \\
(.004)\end{array}$ \\
\hline Capital Intensity & $\begin{array}{l}-.012 \\
(.012)\end{array}$ & $\begin{array}{l}-019 \\
(.015)\end{array}$ & $\begin{array}{l}.012 \\
(.014)\end{array}$ & $\begin{array}{l}-.018 \\
(.015)\end{array}$ \\
\hline Produce $_{t-1}$ & $\begin{array}{l}.174^{\mathrm{a}} \\
(.011)\end{array}$ & $\begin{array}{l}.398^{\mathrm{a}} \\
(.011)\end{array}$ & $\begin{array}{l}.174^{\mathrm{a}} \\
(.011)\end{array}$ & $\begin{array}{l}.399^{\mathrm{a}} \\
(.011)\end{array}$ \\
\hline $\begin{array}{l}\text { Produce }_{\mathrm{t}-1} \\
\quad * \text { US \% }\end{array}$ & $\begin{array}{l}-.138^{\mathrm{a}} \\
(.026)\end{array}$ & $\begin{array}{l}-.252^{\mathrm{a}} \\
(.022)\end{array}$ & $\begin{array}{l}-.138^{\mathrm{a}} \\
(.026)\end{array}$ & $\begin{array}{l}-.252^{\mathrm{a}} \\
(.022)\end{array}$ \\
\hline Controls & \multicolumn{2}{|c|}{ Year, Country-SIC4 } & \multicolumn{2}{|c|}{ Year, Country-SIC4 } \\
\hline $\mathrm{R}^{2}$ & \multicolumn{2}{|c|}{.120} & \multicolumn{2}{|c|}{.123} \\
\hline Observations & \multicolumn{2}{|c|}{47.936} & \multicolumn{2}{|c|}{47,936} \\
\hline
\end{tabular}

Notes: Standard Errors in ( ). The regressions are estimated by fixed effects [FE]. The subscripts ${ }^{\mathrm{a}},{ }^{\mathrm{b}}$ and ${ }^{\mathrm{c}}$ represent statistical significance at the 1,5 and $10 \%$ respectively. Competitor Count describes how competitor counts were defined in the interaction terms. 


\section{Data Appendix}

OAP Imports

The import data are taken from United States International Trade Commission (USITC) reports on 806/807 and 9082 imports. Between 1980 and 1988 the data on OAP import values originate from information on 806/807 imports from the Tariff Schedule of the United States, and the provisions of 9802 under the Harmonized System for the years 1989 to 1994. The product level data from these programs were then aggregated to the 4-digit SIC industry using the concordance constructed by Robert Feenstra, and available from the National Bureau of Economic Research, at http://www.nber.org/data_index.html.

The relative contribution of U.S.-origin parts and materials is computed as declared inputs that are U.S. origin divided by the full declared value of the OAP imports. When I construct equation (4) cost measures industry-country sample averages of $\alpha_{u s, \text { ic }}$ are used. While Feenstra, Hanson and Swenson (2000) note that country costs affect U.S. input shares $\left(\alpha_{\mathrm{us}, \mathrm{ic}}\right)$ of OAP producers, the small size of these responses support the Leontieff assumption.

\section{Country Variables}

The real price of GDP taken from the Penn World Table at http://pwt.econ.upenn.edu/, was used to measure country costs in the production cost equations. While the equations are based on wages, country costs were selected for two reasons. First, since production includes more than wages, country price levels may provide better insight into the cost of input bundles. Second, the availability of the price data for more years and countries makes it an attractive candidate for this project. Alan Heston, Robert Summers and Bettina Aten, Penn World Table Version 6.1, Center for International Comparisons at the University of Pennsylvania (CICUP), October 2002.

\section{Industry Characteristics}

Transportation costs were constructed from Robert C. Feenstra's data "U.S. Imports and Exports by 4-digit SIC Industry, 1958-94" which are posted and described at http://data.econ.ucdavis.edu/international/usixd/usixd4sic.html. I assume that the cost of transporting inputs in industry $i$ is the same as the cost of transporting final goods in industry $i$, since there is no detailed information on composition of input trade that would enable me to apply transportation costs for U.S. inputs that are shipped abroad for foreign assembly. Tariff data were taken from Chris Magee's "U.S. Tariffs at the SIC Level, 1974-1988, which are available from data.econ.ucdavis.edu/international/ustariff.html. Since the tariff series ends before the time analyzed, the 1987 tariff is used for each industry. Data on U.S. industry characteristics were collected from the NBER Manufacturing Database, at http://www.nber.org/data_index.html, as constructed by Bartlesman, Becker and Gray. Industry capital intensity was measured by capital/output.

\section{Summary Statistics for Measure of Own Cost [SD = standard deviation]}

Variable Name Full Sample Mean(SD) OECD Mean(SD) non-OECD Mean(SD)

Own Cost

4.578
4.755

(.201)
4.426 


\section{References}

Baldwin, Richard E. (1988) "Hysteresis in Import Prices: The Beachhead Effect." American Economic Review, September, 78(4):773-85.

Baldwin, Richard E. and Krugman, Paul R. (1989) "Persistent Trade Effects of Large Exchange Rate Shocks." Quarterly Journal of Economic, 104(4): 635-54.

Bernard, Andrew B., Jensen, J. Bradford and Peter K. Schott. (2006) "Survival of the Best Fit: Exposure to Low Wage Countries and the (Uneven) Growth of US Manufacturing Plants" Journal of International Economics, 68(1): 219-237.

Bernard, Andrew B., and Bradford J. Jensen, (2004) "Why Some Firms Export," The Review of Economics and Statistics, 86(2): 561-569.

Besedes, Tibor and Thomas J. Prusa. (2004) "A Search Cost Perspective on Duration of Trade" Rutgers Manuscript.

Blonigen, Bruce A. and Ronald B. Davies. (2004) "The Effects of Bilateral Tax Treaties on US FDI Activity," International Tax and Public Finance 11(5), 601-22.

Blonigen, Bruce A. and Miao Grace Wang. (2005) "The Inappropriate Pooling of Wealthy and Poor Countries in Empirical FDI Studies.” In Moran, Theodore H., Graham, Edward M. and Blomstrom, Magnus eds. Does Foreign Direct Investment Promote Development? Washington D.C.: Institute for International Economics, 221-244.

Campa, Jose (2004). "Exchange Rates and Trade: How Important is Hysteresis in Trade?" European Economic Review, 48: 527-548.

Das, Sanghamitra, Mark J. Roberts, and James R. Tybout (2006) "Market Entry Costs, Producer Heterogeneity, and Export Dynamics.” Pennsylvania State University Manuscript.

Deardorff, Alan V. (2001) "Fragmentation across Cones," in Arndt, Sven W. and Henryk Kierzkowski (eds.), Fragmentation: New Production Patterns in the World Economy, Oxford:Oxford University Press, 35-51.

Dixit, Avinash. (1989) "Hysteresis, Import Penetration, and Exchange Rate Pass-Through." Quarterly Journal of Economics, May, 104(2): 205-28.

Evans, Carolyn L. and James Harrigan. (2005). "Distance, Time and Specialization: Lean Retailing in General Equilibrium," American Economic Review. March 2005, v. 95 no. 1, 292313.

Feenstra, Robert C. (1998) "Integration of Trade and Disintegration of Production in the Global Economy," Journal of Economic Perspectives, 12(4): 31-50.

Feenstra, Robert C., and Gordon H. Hanson, and Deborah L. Swenson, (2000) "Offshore Assembly from the United States: Production Characteristics of the 9802 Program," in Robert C. Feenstra, editor, The Impact of International Trade on Wages, Chicago, IL: University of Chicago Press, 85-122. 
Goldberg, Pinelopi and Michael M. Knetter (1999) "Measuring the Intensity of Competition in Export Markets" Journal of International Economics, 47:27-60.

Gorg, Holger, (2000). "Fragmentation and trade: US inward processing trade in the EU." Weltwirtschaftliches Archiv - Review of World Economics, V136(N3):403-422.

Greenhut, M.L. and H. Ohta, (1979). "Vertical Integrations of Successive Oligopolists." American Ecomomic Review, 69:137-141.

Grossman, Gene M. and Elhanan Helpman. (2005) "Outsourcing in a Global Economy," Review of Economic Studies, 72(1).

Head, Keith and John Ries, (2002) "Offshore Production and skill upgrading by Japanese Manufacturing Firms" Journal of International Economics, October, 58(1):81-105.

Hummels, David, Jun Ishii and Kei-Mu Yi (2001), "The Nature and Growth of Vertical Specialization in World Trade," Journal of International Economics, June, V54(N1):75-96.

Krugman, Paul R. (1989). Exchange Rate Instability. Cambridge: MIT Press.

McLaren, John. (2000), "Globalization' and Vertical Structure," American Economic Review, 90(5): 1239-1254.

Mendez, Jose A. (1993) "The Welfare Effects of Repealing the U.S. Offshore Assembly Provision," Journal of International Economics, 34:1-22.

Ng, Francis and Alexander Yeats (2001). "Production Sharing in East Asia: Who does what for whom, and Why? in Leonard K. Cheng and Henryk Kierkowski (eds), Global Production and Trade in East Asia, Boston: Kluwer Academic Publishers, 63-109.

Rauch, James E., (1999). "Networks versus Markets in International Trade," Journal of International Economics 48(1): 7-35.

Rauch, James E. and J. Watson. (2003) "Starting Small in an Unfamiliar Environment," International Journal of Industrial Organization, 21:1021-1042.

Roberts Mark J. and James Tybout. (1997) "The Decision to Export in Columbia: An Empirical Model of Entry with Sunk Costs." American Economic Review, 87(4), 545-564.

Rodrik, Dani. (1997) "Has Globalization Gone too Far?" Washington, D.C.: Institute for International Economics.

Schott, Peter K. (2002) "Moving Up and Moving Out: Product Level Exports and Competition from Low Wage Countries," Yale School of Management manuscript.

Spencer, Barbara J. (2005) "International Outsourcing and Incomplete Contracts," Canadian Journal of Economics, 38(4): 1107-1135.

Swenson, Deborah L. (2005) "Overseas assembly and country sourcing choices" Journal of International Economics, 66(1): 107-130. 
Yeats, Alexander (2001) “Just How Big is Global Production Sharing?", in Sven W. Arndt and Henryk Kierzkowski (eds), Fragmentation: New Production Patterns in the World Economy, New York: Oxford University Press, 108-143.

Yi, Kei-mu, (2003). "Can Vertical Specialization explain the Growth of World Trade?" Journal of Political Economy. 111(1):52-102, 2003 Feb. 